\title{
Seasonal Variation of Thermocline Depth: Consequence on Nutrient Availability in the Ivorian Coastal Zone
}

\author{
Kassi Ahon Jean-Baptiste, PhD
}

Département des Géosciences Marines, UFR des Sciences de la Terre et des

Ressources Minieres, Universite Felix Houphouet-Boigny,

Abidjan, Côte d'Ivoire

Centre Universitaire de Recherche et d;Application en teledetection

(CURAT) Abidjan, Côte d'Ivoire

\section{Mobio Abaka Brice Herve, PhD}

Département des Géosciences Marines, UFR des Sciences de la Terre et des

Ressources Minieres, Universite Felix Houphouet-Boigny

Centre Universitaire de Recherche et d;Application en teledetection

(CURAT) Abidjan, Côte d'Ivoire

\section{Kouadio Maffoue Jeanne, PhD}

UFR des Sciences de la Terre et des Ressources Minieres, Universite Felix

Houphouet-Boigny

Centre Universitaire de Recherche et d;Application en teledetection

(CURAT) Abidjan, Côte d'Ivoire

Tiemele Jacques Andre, PhD

Centre Universitaire de Recherche et d;Application en teledetection

(CURAT) Abidjan, Côte d'Ivoire

Doi: 10.19044/esj.2017.v13n33p215 URL:http://dx.doi.org/10.19044/esj.2017.v13n33p215

\begin{abstract}
Faced with the threat of overfishing in Africa, this study was initiated in the coastal zone of Côte d'Ivoire to understand the nutrients availability as function of variation in the depth of thermocline. Data from the ocean bank, World Ocean Atlas (WOA), were used in the ODV software during the twelve months of 2009 taken at $5.5^{\circ} \mathrm{W} / 4.5^{\circ} \mathrm{N}$ (station coordinates). ODV software has allowed to make seasonal analysis, from vertical profiles and latitudinal analysis from the coast toward the sea through some parameters such as temperature, nitrate, phosphate and oxygen. The depth of thermocline, nitracline, phosphacline and oxycline was determined by the seasonal analysis. To evaluate the enrichment intensity of coast towards the sea, latitudinal analysis was investigated using the section profiles $\left(1^{\circ} \mathrm{S} / 5^{\circ} \mathrm{N}\right.$
\end{abstract}


coordinates). The main results have shown not only the variation in the depth of the thermocline, but also the variation of nitracline, phosphacline and oxycline at different marine seasons. During the cold season, there was an ascent of the thermocline over the surface of water and a strong enrichment from the coast to the sea especially in August. While in hot season, the thermocline was lower and its stability has favoured the stratification of the water column, which prevents the enrichment of the oxygenated surface layer. Analysis of relationships shows that nutrient elements and oxygen change polynomially with temperature.

Keywords: Thermocline, temperature, nitrate, phosphate, oxygen, Côte d'Ivoire

\section{Introduction}

Côte d'Ivoire maritime facade (towards South Atlantic), is an environment influenced by several variable parameters such as temperature, rainfall, swell, tide, salinity, wind, density, current river flows, etc. Among the phenomena affecting this environment, upwelling governing the spatial and temporal dynamics of fishery resources seems to be one of the most unstable. Indeed, these resources are mostly located in upwelling areas (Bainbridge, 1960; Binet, 1983). Upwelling is a phenomenon of unexpected drop of sea surface temperature caused by cold water ascent rich in nutrients and suitable for primary production in these coastal regions. This coastal resurgence is possible because of the rise of the thermocline, which is the limit separating two layers of water bodies with different thermal gradients. This is a very important parameter of vertical distribution of the planktonic community. It represents a medium temperature zone favorable to marine life. There are indeed light and nutrients from the decomposition of organisms. Several studies in the marine environment have shown thermocline spatial and temporal variability (Cury and Roy, 1987; Arfi et al, 1993). This variation drives stratification or stability of water column.

In Côte d'Ivoire, several reports (Wooster et al., 1976; Djagoua, 2003; Kassi 2007; Djagoua et al., 2011; Kassi et al., 2014) have indicated a very marked seasonal variation in the temperature characterizing upwelling. Depending on thermocline depth with regard to the surface, upwelling may be more or less intense (Cury and Roy, 1987; Arfi et al 1993). In addition, this intensity can induce enrichment in nutrients of the marine environment necessary to the maintenance of marine life (Djagoua et al, 2011). Therefore, this study was initiated in order to understand the influence of the thermocline on nutrients availability. To achieve this objective, a study of the seasonal variation in temperature, oxygen, nitrate and phosphate along with a vertical profile was performed to determine the depths of thermocline. Then, 
this was followed by a latitudinal study of those parameters to finally establish the relationship between the depths of the thermocline and those of nitracline, phosphacline and oxycline.

\section{Materials and Methods}

\section{Data}

Data used in this study were collected from the oceanographic surveys of the World Ocean Circulation Experiment (WOCE) from 2009. Mostly measured parameters are temperature, salinity, oxygen, phosphates, silicates, nitrates, nitrites, ChloroFluoroCarbon 11 (CFC-11) and ChloroFluoroCarbon 12 CFC-12. (temperature, phosphate, nitrate and oxygen)

\section{Methodology}

\section{Vertical analysis of parameters}

Sampling point coordinates are $5.5^{\circ} \mathrm{W} / 4.5^{\circ} \mathrm{N}$ (Figure 1). Data were processed through the "Ocean Data View" software (ODV software). This software allows data visualization for a given point in various parameters.

The resulted values were exported to Excel software for seasonal analysis.

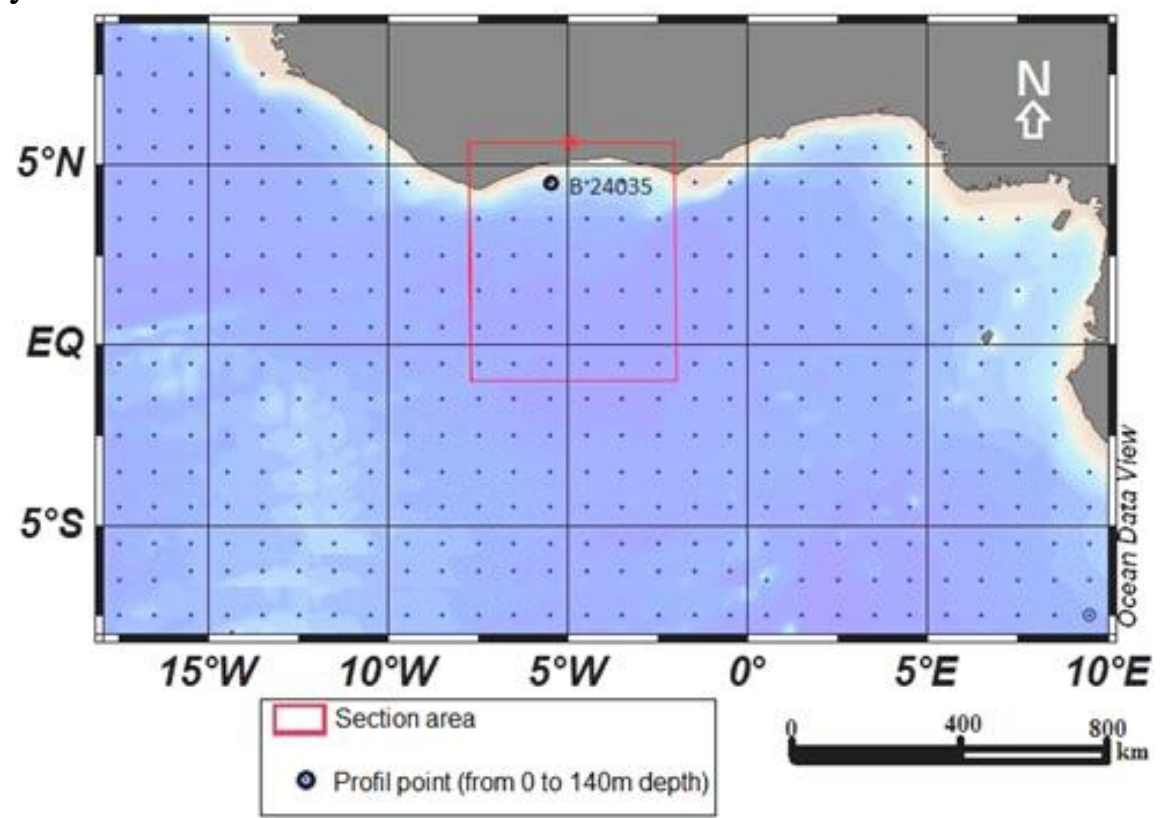

Figure 1: Coordinate section area and point $\left(5.5^{\circ} \mathrm{W} / 4.5^{\circ} \mathrm{N}\right)$ where the profile was made up to $140 \mathrm{~m}$ for the thermocline determination 


\section{Latitudinal analysis of parameters}

This latitudinal analysis (from the coast to the sea on the one hand and from the surface to the depth, on the other hand) aims to characterize the extent of enrichment and evolution of its intensity with distance. The configuration mode (section) of ODV software was chosen. This mode shows different graphical representations in sections and the value of the parameters along the path (from the coast toward the sea).

\section{Analyzes of the relationship between temperature and measured parameters}

The determination of phosphacline and nitracline (zone of strong gradient of phosphate and nitrate) as well as thermocline and oxycline (zone of drop of temperature and oxygen) were carried out through analysis of the depth of the various parameters.

To determine the thermocline, one must ensure that all the sun rays that hit the surface of the ocean are absorbed by the upper layer that warms. Wind and waves circulate this water distributing heat uniformly on the first tens of meters of depth. Thus, temperature profile is generated. From $0 \mathrm{~m}$, the vertical or sub-vertical plane characterizing surface layer is drawn. Below this limit, the profile has a sudden drop in temperature with depth: it is thermocline or metalimnion. Below this limit, the temperature drops, but slowly (Figure 2). These differences are determined following the same method.

To establish the relationship between temperature and parameters, it was demonstrated how the parameters measured vary as a function of the temperature (Figure 2). Longitudinal analysis aims to characterize the extent of enrichment and evolution of its intensity with distance.

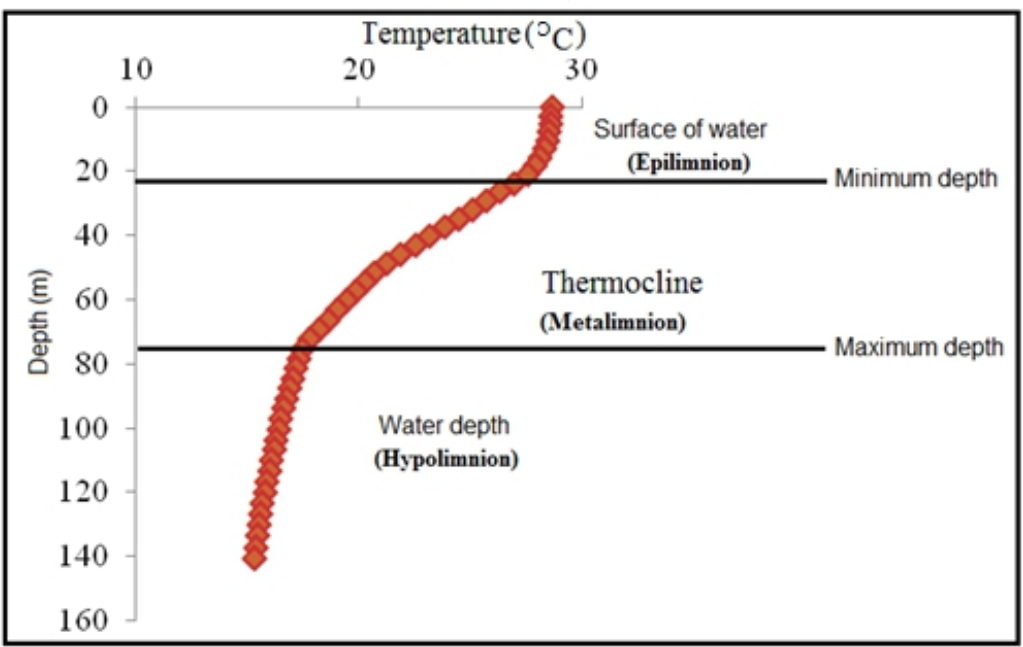

Figure 2: Thermocline or Metalimnion determination at the point of coordinates $5.5^{\circ} \mathrm{W} /$ $4.5^{\circ} \mathrm{N}$ in 2009 


\section{Results}

\section{Seasonal vertical distribution of the parameters}

\section{Temperature}

The temperature profile over the twelve months showed a strong increase of the thermocline in July, August, September. That corresponding to the great oceanic cold season, and a slight increase in January and February. notice that from March to May and October to November the thermocline drops (Figure 3).

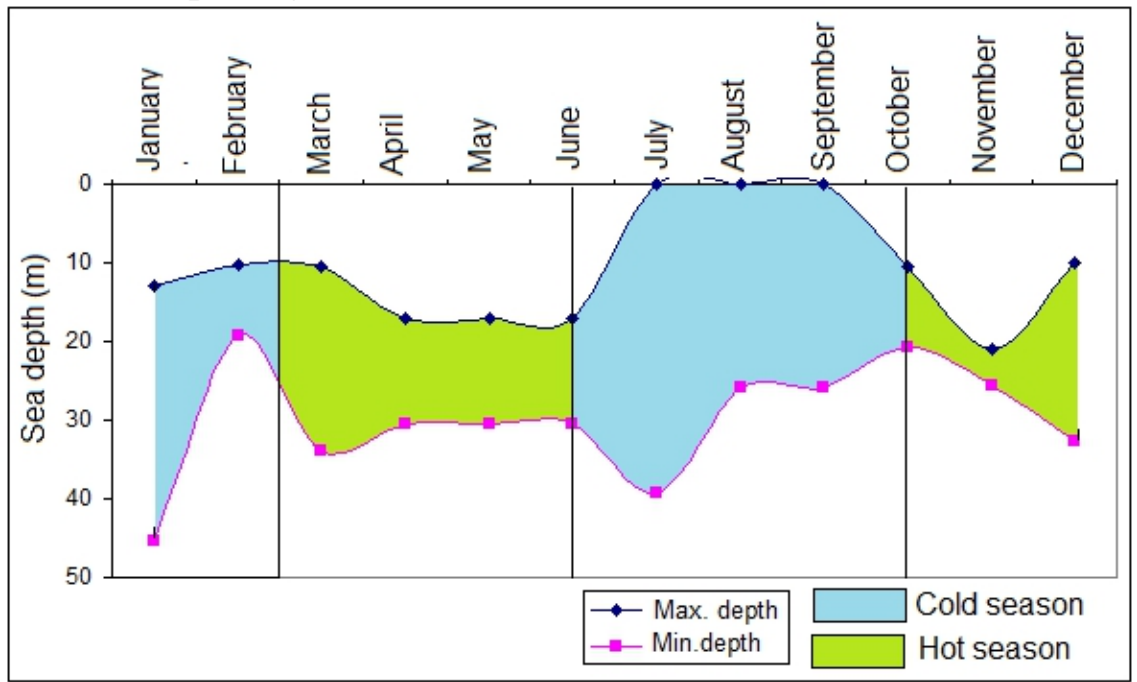

Figure 3: Seasonal vertical distribution of temperature at the point of coordinates $5.5^{\circ} \mathrm{W} / 4.5^{\circ} \mathrm{N}$ in 2009

\section{Nutrients}

The vertical distribution of nutrient elements showed a decrease in phosphacline from January to April then gradually increases to stabilize around $50 \mathrm{~m}$ depth in September and remains more or less constant until December (Figure 4A). Concerning the Nitracline, a rapid increase from January to March was observed, followed by a rapid decrease up to a minimum in September of about $70 \mathrm{~m}$ depth and then further increase in October to reach a steady level until December (Figure 4B). 


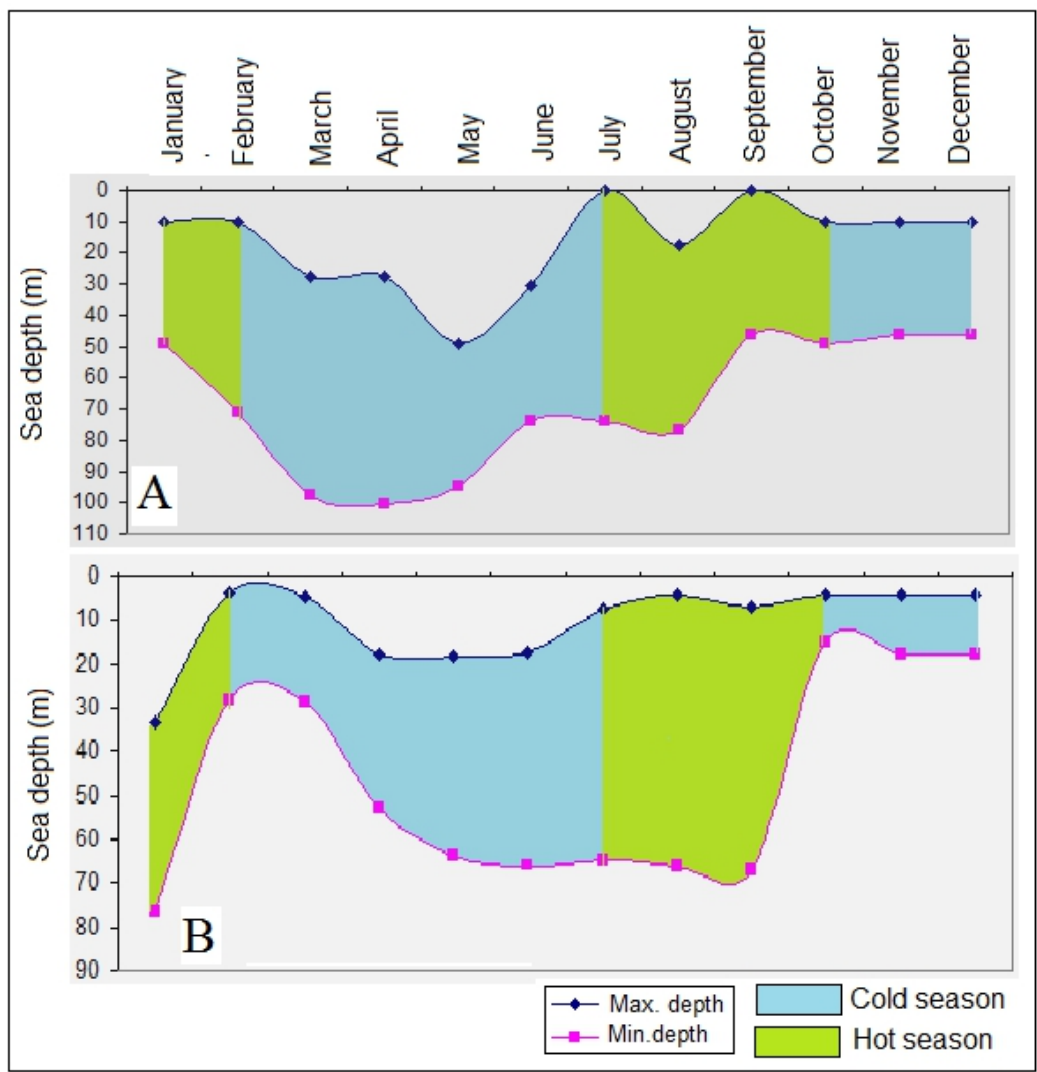

Figure 4: Seasonal vertical distribution of phosphacline (A) and nitracline (B) at the point of coordinates $5.5^{\circ} \mathrm{W} / 4.5^{\circ} \mathrm{N}$ in 2009

\section{Oxygen}

The oxycline or the sub-superficial minimum of oxygen delimits the different zones in the water column. Indeed, from the oxycline, the zones of oxygen presence and oxygen absence (located on either side of the oxycline) can be determined. Thus, as it can be seen in the vertical distribution of oxycline from January to March, the oxygenated layer has a very small thickness. From June to September, the oxycline over the surface, the oxygenated layer disappeared the depth layer less oxygenated. reached a considerable thickness which is about $49 \mathrm{~m}$. The oxygenated layer from October to December is thicker (from 0 to $30 \mathrm{~m}$ ) than in April and May (Figure 5 


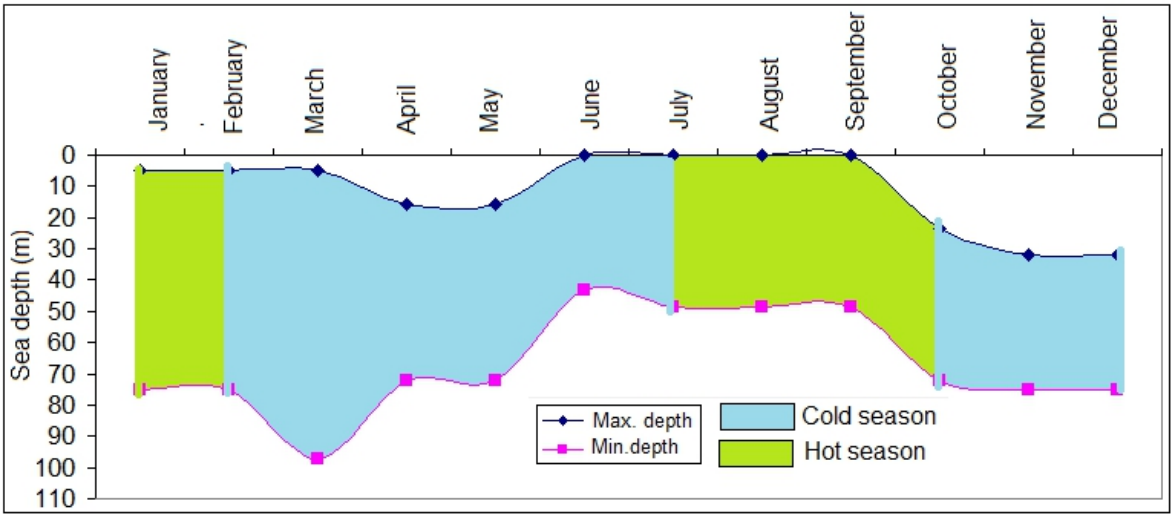

Figure 5: Seasonal vertical distribution of oxycline at the point of coordinates $5.5^{\circ} \mathrm{W} / 4.5^{\circ} \mathrm{N}$ in 2009

\section{Latitudinal variation in January}

The latitudinal variation of temperature, phosphate, nitrate and oxygen is shown in Figure 6. The results showed a small ascent of isotherms $27.5^{\circ} \mathrm{C}$ and $25^{\circ} \mathrm{C}$ close to the coast between $4^{\circ} \mathrm{N}$ and $5^{\circ} \mathrm{N}$ in January. At the same time, a small increase of nitrate level was observed. The level curve of $5 \mu \mathrm{mol} / \mathrm{L}$ is found on the surface. The nitracline in January starts at about 10 $\mathrm{m}$ depth with a nitrate concentration of $5.89 \mu \mathrm{mol} / \mathrm{L}$ while the phosphacline starts at $33.25 \mathrm{~m}$ with concentration of $0.23 \mu \mathrm{mol} / \mathrm{L}$. There is also a slight increase of the curve level of 0.6 and $1 \mu \mathrm{mol} / \mathrm{L}$ near the coast. During this month, the oxycline varied between 5.14 and $75.29 \mathrm{~m}$ depth. The oxycline in the water column separates the oxygenated surface layer and the nonoxygenated layer. This month's, oxygen section shows a rise in oxygen-poor deep waters at the coast. There was a rise of nitracline and oxycline at the coast (between $5^{\circ} \mathrm{N}$ and $4^{\circ} \mathrm{N}$ ), but not at offshore. There was also a slight ascent of the thermocline to the coast and offshore. As for phosphate, there was no increase of phosphacline near and off the coast (Figure 6). 

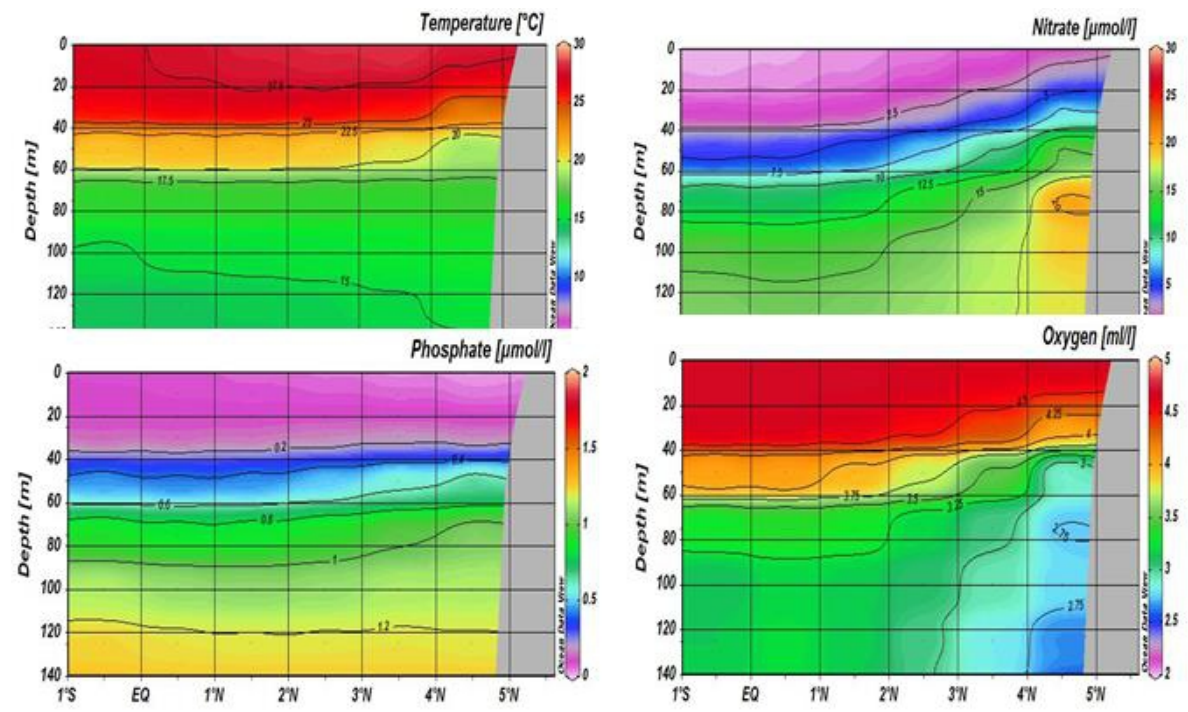

Figure 6 : Latitudinal variation of temperature, nutrient and oxygen in January at the point of coordinates $5.5^{\circ} \mathrm{W} / 4.5^{\circ} \mathrm{N}$ in 2009

\section{Latitudinal variation in May}

The latitudinal section of spatial variation of temperature in May showed a descent of the isotherm $27.5^{\circ} \mathrm{C}$ in depth (Figure 7). On the coast as in sea, there is no rise of the isotherm $25^{\circ} \mathrm{C}$. The surface temperature is high, close to $30^{\circ} \mathrm{C}$ and increases from the coast to the sea the level curve 2.5 and $5 \mu \mathrm{mol} / \mathrm{L}$ of nitrate are at $40 \mathrm{~m}$, indicating a surface layer depletion in nitrate (nitracline about $49 \mathrm{~m}$ ). Regarding the level of the phosphate concentration, the surface layer between 0 and $18.35 \mathrm{~m}$ shows a phosphate depletion (concentration on the surface tends towards $0 \mu \mathrm{mol} / \mathrm{L}$ ). The oxygen section shows a descent of the isolines $(4.5$ and $4.25 \mathrm{ml} / \mathrm{L})$ which represent the oxygen concentration levels at the coast and offshore, suggesting an increase of the thickness of the oxygenated layer because of the oxycline descent. This month is characterized by nutrient depletion from the coastal waters, water oxygenation to the coast and offshore as well as an increase in the surface temperature. 

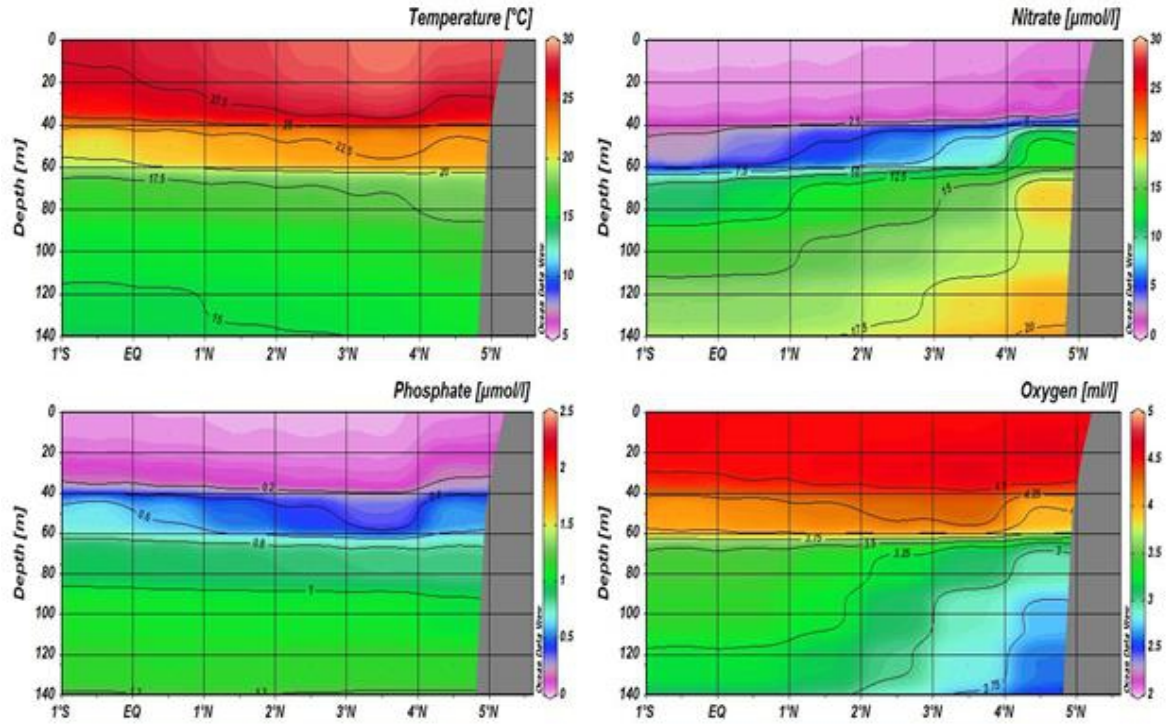

Figure 7 : Latitudinal variation of temperature, nutrient salts and oxygen in May at the point of coordinates $5.5^{\circ} \mathrm{W} / 4.5^{\circ} \mathrm{N}$ in 2009

\section{Variation in latitude in August}

Generally, the rise of thermocline, oxycline, nitracline and phosphacline is observed from the coast toward the sea. There is also a strong cooling and enrichment of the waters in the same way with a decrease in the concentration of oxygen over the whole section. In August, the isotherms $27.5^{\circ} \mathrm{C}$ and $25^{\circ} \mathrm{C}$ disappear over the whole section while an increase of the isotherms $22.5^{\circ} \mathrm{C}$ and $20^{\circ} \mathrm{C}$ is observed (Figure 8). This indicates an increase in nitrate concentration $(7.5 \mu \mathrm{mol} / \mathrm{L})$ offshore at the equator and an accumulation of $5 \mu \mathrm{mol} / \mathrm{L}$ through a cyclonic eddy toward the coast. A rise of all curves of phosphate concentrations over the whole section is noted. The layer above the phosphacline between 0 and $4.27 \mu \mathrm{mol} / \mathrm{L}$ is enriched in phosphate compared to the month of May. The low oxygen concentrations gradually increased from the coast to the sea. The thickness of the oxygenated layer becomes weak at the coast and tends to disappear. 

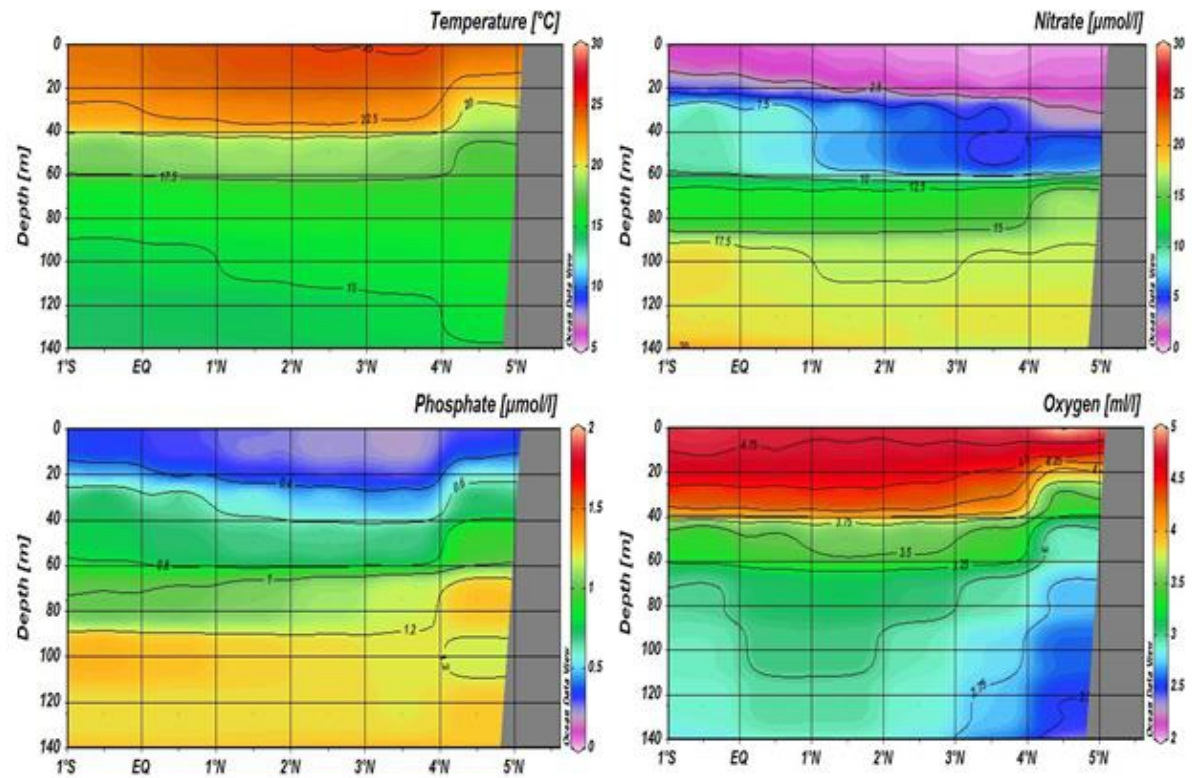

Figure 8 : Latitudinal variation of temperature, nutrient salts and oxygen in August at the point of coordinates $5.5^{\circ} \mathrm{W} / 4.5^{\circ} \mathrm{N}$ in 2009

\section{Latitudinal variation in October}

October presented similar characteristics as of August. Nitracline and phosphacline go back to the coast as also oxycline The difference is about the intensity of enrichment, which decreases from the coast toward the sea. However, in October a small rise of isotherms $25^{\circ} \mathrm{C}$ and $22{ }^{\circ} \mathrm{C}$ occured to the coast. The thermocline is close to the surface near the coast, but deepens offshore. The surface layer has a higher temperature compared to that of August. There is a strong rise in curves of nitrate and phosphate concentration between $1^{\circ} \mathrm{N}$ and $5^{\circ} \mathrm{N}$ and a rise of oxycline throughout the section (Figure 9). The rise of all the curves of the coast shows an enrichment of coastal waters in phosphate and nitrate compared to offshore. 

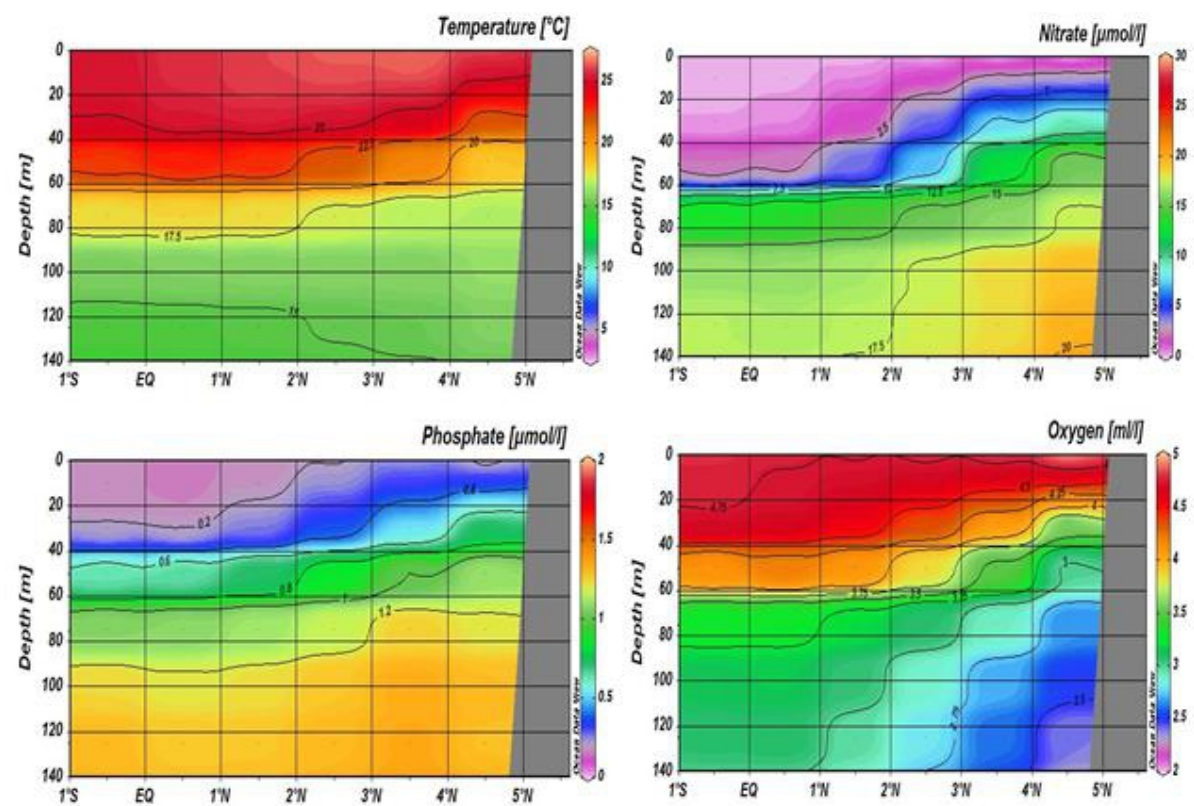

Figure 9: Latitudinal variation in temperature, nutrients and oxygen during in October at the point of coordinates $5.5^{\circ} \mathrm{W} / 4.5^{\circ} \mathrm{N}$ in 2009

\section{Latitudinal variation in December}

In December, the reappearance of the isotherms $27.5^{\circ} \mathrm{C}$ and $25^{\circ} \mathrm{C}$ is observed on the coast. The offshore temperature is lower than that of the coast. It also notes the reappearance of the $0.2 \mathrm{~mol} / \mathrm{L}$ curve at the coast and the layer above the phosphacline between 0 and $4,27 \mathrm{~m}$ becomes poor in phosphate. In addition, the isoline $4.75 \mathrm{ml} / \mathrm{L}$ of oxygen is found towards the sea, indicating that the coast is less oxygenated than the sea. During this month, the waters become warmer and nutrient depleted (Figure 10). The nitracline increases slightly at the coast, in contrast to oxycline and phosphacline. There is an accumulation of nitrate-rich waters with high oxygenation offshore. Furthermore, there is a slight rise of the thermocline of the coast. 

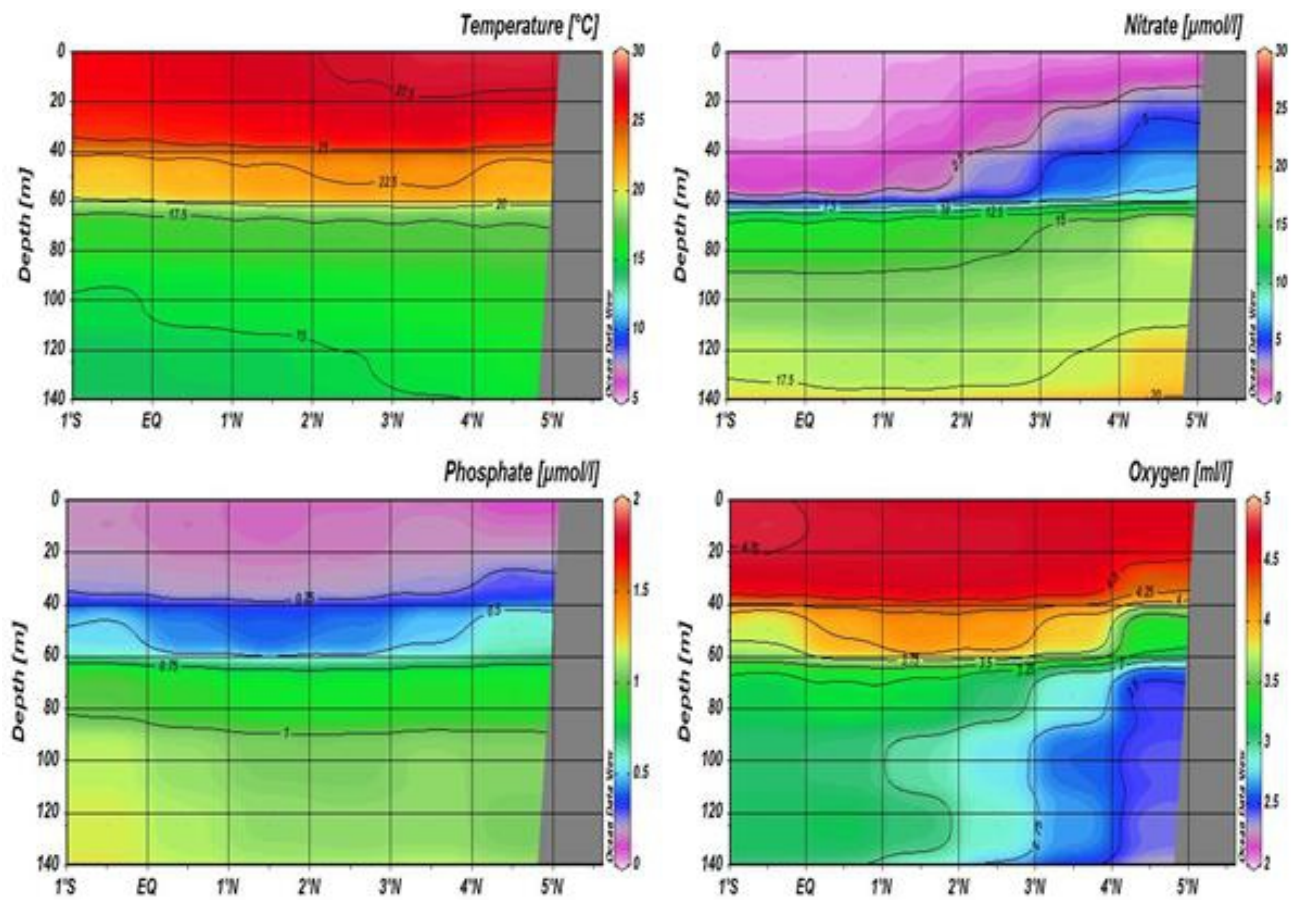

Figure 10: Latitudinal variation in temperature, nutrients and oxygen in December at the point of coordinates $5.5^{\circ} \mathrm{W} / 4.5^{\circ} \mathrm{N}$ in 2009

\section{Relationship between temperature and measured parameters.}

The analysis of relationships shows that nutrient (phosphate and nitrate) and oxygen changed polynomially with temperature. Indeed, the relationship between temperature and nutrient presents a "vault" that demonstrates the existence of a temperature, characterized by maximum concentrations on either side, from which the phosphate and nitrate concentrations decrease (Figures 11a and 11b). The analysis indicates that for high temperature above the threshold value $\mathrm{Ts}=6.5^{\circ} \mathrm{C}$, a rapid drop in the phosphate concentration (Figure 11a) is observed. As concern the nitrate, there is a rapid drop above the temperature threshold of $7.5^{\circ} \mathrm{C}$ (Figure 11b). The oxygen plot presents a cuvette shape with a threshold temperature of $11.25^{\circ} \mathrm{C}$ characterized by minimum oxygen concentrations. On either side of this threshold value, the oxygen concentration increases (Figure 11c). The relationship between temperature and the three parameters is not linear but has a threshold. Beyond this threshold, the correlation with temperature is inverse for nitrate and phosphate, but positive for oxygen with a small amplitude. The oxycline in the water column allows to delineate the oxygenated zone and the non-oxygenated zone. 

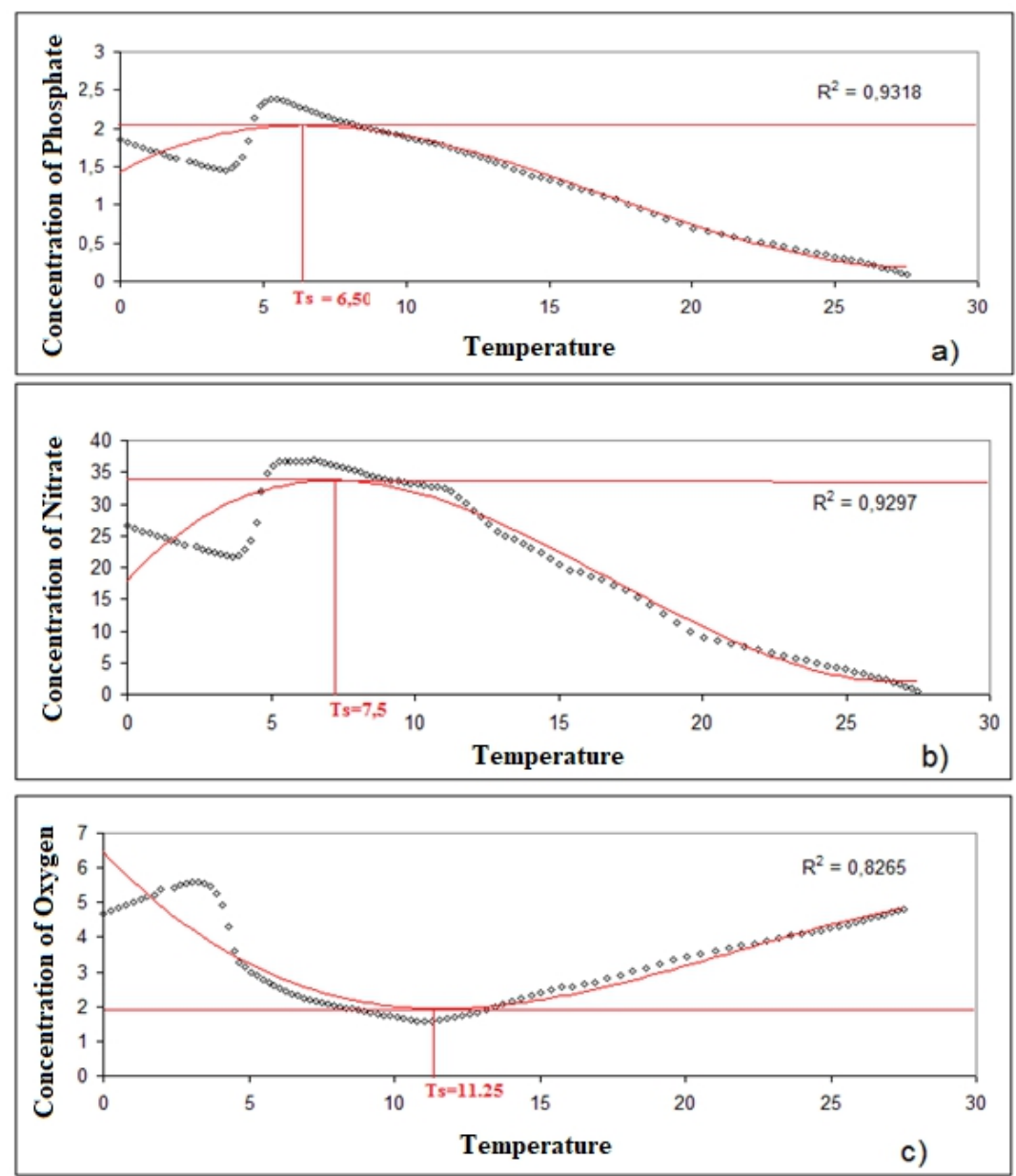

Figure 11: Relationship between temperature $\left({ }^{0} \mathrm{C}\right)$ and phosphate $(\mu \mathrm{mol} / l)(\mathrm{a})$, between temperature and nitrate $(\mu \mathrm{mol} / \mathrm{l})(\mathrm{b})$ and between temperature and oxygen $(\mathrm{mg} / \mathrm{l})(\mathrm{c})$

\section{Discussion}

The results of the analysis show that the temperature is not homogeneous along the entire length of the water column. However, there is an area of homogeneity such as the surface layer. Also, the temperature variation is at the origin of the formation of the thermocline of oceans. This sudden drop of the temperature, which is the thermocline promotes the stability in the water column, thus preventing any ascendant movement. The non-climbing of nutrient with in the thermocline drives nutrient depletion near the surface layer. This prevents the abundance of life in this part of the ocean if the terrigenous input is ignored. Therefore, the primary production could only become important in the part of the euphotic zone characterized by a depth of nitracline at a low level of illumination, where mineral salts 
will be found, i.e., where the thermocline is shallow, therefore an area of maximum chlorophyll (Dugdale, 1967).

The nutrient such as phosphate and nitrate have a great responsibility in fish productivity in the ocean. Our results show that the top of the phosphacline is shallower than that of nitracline. Several studies have shown that the thermocline affects the distribution of nutrients (Dugdale, 1976; Barber et al., 1981). In the hot season, it constitutes a barrier to the rise of nutrient salts and during the cold season, the instability in the water column, due to the upwelling phenomenon, favors the rise of the thermocline. However, the small cold season (January-February) exhibiting a low rise of the thermocline, which therefore reveals nutrients to the surface. On the other hand, the upwelling from July to September is clearly visible and shows the greatest rise of the thermocline (Molière and Rebert, 1972). Upwelling is a physical process that results in the migration of rich surface waters that promote the proliferation of plankton and therefore fish. Several hypotheses have been proposed to explain this phenomenon along Côte d'Ivoire coastline (Ingham, 1970; Moore et al., 1978; Severain et al., 1982; Picaut, 1983). The most obvious manifestation of a coastal upwelling is the formation of the temperature gradient between the coast and the offshore. This characteristic enabled Wooster et al. (1976) to locate the main coastal upwelling zones and their intensities in West Africa from the temperature differences measured between the coast and the sea. The stratification of the water column during the hot season and upwelling in cold season observed in the Ivorian coastal zone are similar to processes that occur on both sides of the equator at different seasons in pacific ocean which affects the terrestrial climate of several countries of the world. These are El Niño (heating of the surface water reservoir) and La Niña (elevation of the thermocline) phenomena. When the thermocline rises, the nitracline and phosphacline are close to the surface since the well-developed thermocline during the hot season reaches the surface in the cold season for the measurement of high nutrient values. This relationship between the thermocline and nitracline allowed Herbland and Voituriez in 1979 to establish from the temperature data a mapping of the depth of nitracline that revealed the intensity of primary production in the water column. The enrichment of the surface layer could come from an external contribution such as runoff water and the flood of rivers flowing into the sea. This phenomenon is mostly observed in October with a strong phosphate gradient present in the surface layer. Besides the nutritive salts, oxygen also plays an important role in the ocean. The content of dissolved gases, particularly oxygen, depends on the contact with the atmosphere, the water temperature and the plankton activity. This means that the vertical exchanges of oxygen in the water column are caused by physical but also biological processes. Thus, the minimum oxygen 
observed in the thermocline could be explained by the breathing of the organisms. In the hot season, the stratification of the water column due to the presence of thermocline promotes the strong heating of the surface layer by the solar rays and the evaporation of the dissolved oxygen formed in the cold season by photosynthesis since this layer is at water/atmosphere interface. The ocean under the action of marine surface currents caused by winds, carries the heat from the surface layers of the equator to the poles and carries back the oxygen of the poles (lower latitudes) to the deep layers of the equator. This is conditioned by the great oceanic circulation on a global scale (the Gulf Stream).

\section{Conclusion}

To achieve the objective of this study, a seasonal investigation was made to know the depth of the different parameters. This has also led to determine the thermocline, phosphacline, nitracline and oxycline. Thus, a relationship between their different depths (minimum and maximum) was established in order to determine the evolution of these parameters over the twelve months of the year. The World Ocean Atlas data from 2009 processed by the ODV software have shown that the ocean thermocline changes with the sea seasons. In the hot season (March-June and October-December), the thermocline is stable, causing stratification of the water column as well as the poverty of the surface layer since the strong gradient of phosphate and nitrate is found at its level. While, in the cold season (January to February and July to September), the thermocline rises to the surface due to upwelling, which promotes the enrichment of the surface layer of nitrate and phosphate. It should be noted that the depth of the nitracline and the phosphacline depend on the depth of the thermocline, but the upwelling from July to September is more intense than that of January to February showing the greatest rise of the thermocline to the coast.

\section{References:}

1. Arfi R., Peznnnec O., Cissoko S., et Mensah M. (1993). Evolution temporelle d'un indice caractérisantl'intensité de la résurgence ivoiro-ghanéenne.in :environnementet ressources aquatiques de la côte d'ivoire.i-le milieu marin. Paris, orstom, pp.111-122.

2. Bainbridge V. (1960). The plankton of inshore waters of freetown, sierra leone.fishery publications, colonial office, vol.13, 43p.

3. Barber R.T. and Smith. R. L. (1981). Coastal upwelling ecosystems, in: analysis of marine ecosystems, a.Longhurst(ed), academic press, pp 31-68. 
4. Binet D. (1983).Phytoplancton et production primaire des régions côtières à upwelling saisonniers dans le golfe de guinée.Océanogr.trop, vol.18, n² : pp 331-335.

5. Cury P. et Roy C. (1987).Upwelling et pêche des espèces pélagiques côtières de côte d'ivoire: une approche globale.Oceanologica acta, vol .10, n³, pp.347-357.

6. Djagoua E.V., Larouche P., Kassi J-B., Affian K et Saley B (2011). Variabilité saisonnière et interannuelle de la concentration de la chlorophylle dans la zone côtière du golfe de guinée à partir des images seawifs.international journal of remote sensing, 32(14), pp.3851 -3874.

7. Djagoua E. M. V. (2003). Contribution de l'imagerie satellitaire visible et infrarouge thermique à l'étude de la variabilité spatiotemporelle des phénomènes physiques de surface du littoral marin ivoirien et implication dans la variabilité du phytoplancton et des prises de sardinella aurita. Thèse unique, université de cocody (côte d'ivoire) , $117 \mathrm{p}$.

8. Dugdale R.C. (1976).Nutrients cycle in d.h.cushing and jj.walsh, (ed), the ecology of the sea.blackell scient .publ, oxford, p.pp147172.

9. Dugdale R. C. (1967).Nutrient limitation in the sea. Dynamics, identification and significance. limnol.oceanogr. Vol $12 \mathrm{n}^{\circ} 4$, pp. 685695.

10. Herbland A et Voituriez B. (1979). Relation chlorophylle «a » fluorescence in vivo dans l'atlantique tropical. Influence de la structure hydrologique.cah.orstom, ser.oceanogr, vol.15 $\mathrm{n}^{\circ} 1$, pp. 67 77.

11. Ingham M. C. (1970).Coastal upwelling in the northwestern of Gulf of Guinea. Bull.mar.sci, 20, pp.2-34.

12. Kassi J-B., Djagoua E. V., Mobio B. A., Gougnon A. R., Affian K., Tiemele J. A., Kouadio J. M., Dro C. Z.et Kouame A. K. (2014).Determination of the retention areas of pelagic species in ivorian coastal water using remote sensing and geographic information system (gis). International journal of scientific \& engineering research, volume 5, issue 9, september-2014, p869-877.

13. Kassi A. J-B. (2007).Variabilité de l'intensité de l'upwelling ivoiroghanéen et son impact sur la biomasse phytoplanctonique à l'aide du capteur modis du satellite aqua (2002-2005). Mémoire de dea, université de cocody, $45 \mathrm{p}$.

14. Moliere A. et Rebert J-P. (1972).Etude hydrologique du plateau continental ivoirien.doc.scient.cro.abidjan, 3(2) :1-30. 
15. Moore D., Hisard P., M. C.Creary J., Merle J., O'brien J., Picaut J., Verstraete J. M. and Wunsch C. .(1978). Equatorial adjustment in the eastern atlantic, geophys. Res.lett, 5, pp .637-640.

16. Severain J., Picaut J and Merle J. (1982).Evidence of remote forcing in the equatorial atlantic ocean. J.phys oceanogr, 12.pp.457-463.

17. Wooster.W. S. A. Bakun and D. R. Mclain. (1976). The seasonal upwelling cycle along the easten boundary of the north atlantic.j.mar.res. 34: pp 131-141. 